\title{
Prevalence and Five-Year Cumulative Incidence of Abdominal Obesity in Croatian Women of Childbearing Age: the CroHort Study
}

\author{
Kristina Fišter1, Davor Ivankovićc1, Mirko Koršiće ${ }^{2}$, Gordana Pavleković1, Sanja Musić Milanoviće , \\ Silvije Vuletić ${ }^{1}$ and Josipa Kern ${ }^{1}$ \\ ${ }^{1}$ University of Zagreb, School of Medicine, »Andrija Štampar« School of Public Health, Zagreb, Croatia \\ ${ }^{2}$ University of Zagreb, School of Medicine, Zagreb, Croatia \\ ${ }^{3}$ Croatian National Institute of Public Health, Zagreb, Croatia
}

\begin{abstract}
A B S T R A C T
Generalised obesity is increasing in prevalence globally, however trends in abdominal obesity are less well known. In 2003, 1,999 women of childbearing age participated in the Croatian Adult Health Survey, of whom 598 (29.9\%) participated in the second cycle in 2008. For 2008, the prevalence of abdominal obesity using the International Diabetes Federation (IDF) criterion (waist circumference $\geq 80 \mathrm{~cm}$ ) was estimated at 70.3\% (95\% CI 61.8\% to 75.7\%), whereas the prevalence of abdominal obesity using the National Cholesterol Education Program, Adult Treatment Panel III (NCEP ATP III) criterion (waist circumference $\geq 88 \mathrm{~cm}$ ) was estimated at $48.6 \%$ (42.6\% to $54.7 \%$ ). The preceding five-year cumulative incidence was $54.3 \%$ (44.5\% to 64.2\%) and 35.2\% (28.0\% to 42.4\%) using the IDF and NCEP ATP III criteria, respectively. The burden of abdominal obesity is high and rapidly increasing in Croatian women of childbearing age, the key population subgroup for obesity control.
\end{abstract}

Key words: Croatia, Croatian Adult Health Survey, incidence, middle aged, obesity, abdominal, prevalence, women's health, young adult

\section{Introduction}

Preventing obesity is a complex task that involves weight control in pregnant women ${ }^{1}$, interventions in early childhood - when habits are created related to diet and physical activity ${ }^{2}$, adolescence - the age at which peer pressure can lead to increases in unhealthy behaviours ${ }^{3}$, and early adult years - when greatest increases in body weight often occur ${ }^{4,5}$. The importance of addressing the burden of obesity among women of childbearing age has repeatedly been flagged $\mathrm{up}^{6,7}$, and it has recently been proposed that campaigns aimed at reducing obesity rates should primarily focus on women of childbearing age ${ }^{8}$. However, little is known about this population subgroup in obesity research.

Visceral adiposity has been causally linked with morbidity, as well as mortality from cardiovascular disease and type 2 diabetes $^{9}$, the major causes of death and disability worldwide ${ }^{10}$, as well as in Croatia ${ }^{11}$. We therefore set out to study abdominal obesity in Croatian women of childbearing age ${ }^{12}$.
In this report we present population estimates of prevalence and five-year cumulative incidence for abdominal obesity, generalised overweight and obesity, as well as health behaviours thought to be associated with developing these traits - physical inactivity, sedentary lifestyle, unhealthy diet, smoking, and consumption of alcohol.

\section{Methods}

The methodology used in both cycles of the Croatian Adult Health Survey has been described in detail elsewhere $^{13,14}$. Briefly, in 2003 we surveyed 9,070 adults as part of a nationally representative study. Of these, in 2008 we revisited and resurveyed $3,229(35.6 \%)$ of the original participants. Trained visiting nurses conducted the interviews in participants' homes. Data were collected on demographic and socioeconomic factors, health 
behaviours, use of health services, history of chronic diseases, use of drugs, health related and overall quality of life, and perceived stress. Visiting nurses measured waist and hip circumferences, blood pressure, and pulse rate. Weight and height were self reported.

\section{Definitions}

Women of childbearing age were those aged 18 to 44 years at baseline. Of anthropometrical indices, waist circumference has been shown to best correlate with the amount of visceral fat ${ }^{15}$. We measured waist circumference using a tape measure, in a standing position, at the umbilicus level at the end of a light expirium. We defined abdominal obesity using two criteria, as has been recommended: waist circumference $\geq 80 \mathrm{~cm}$ (the International Diabetes Federation or IDF criterion) as well as waist circumference $\geq 88 \mathrm{~cm}$ (the National Cholesterol Education Program, Adult Treatment Panel III or NCEP ATP III criterion) ${ }^{16,17}$. Generalised overweight and obesity were defined using body mass index (weight in kilograms divided by squared height in meters, BMI). Generalised overweight was $25 \leq \mathrm{BMI}<30$ and generalised obesity $\mathrm{BMI} \geq 30$.

We considered physically active those women who were physically active, enough to breathe more heavily or sweat, on average at least 30 minutes each day at least four days each week (possible activities included but were not limited to hiking, running, riding a bicycle, gym, swimming, and house work); or they walked or rode a bicycle to and from work in the duration of at least 30 minutes each work day. Sedentary lifestyle was characterised by meeting at least two of three criteria: regularly using transportation to get to and from work (car, public transport, motorcycle, or the like); mostly sitting at work; in leisure time, never or only several times each year being physically active enough to breathe more heavily or sweat, for at least 30 minutes (possible activities included but were not limited to hiking, running, riding a bicycle, gym, swimming, and house work).

To assess dietary habits, we used exploratory factor analysis based on a food frequency questionnaire; we used principal component analysis and oblique rotation. Two factors were retained, representing a healthy (rich in fruits, legumes, and varied vegetables, except for potatoes, and preferring freshly squeezed juices over sodas) and an unhealthy (rich in sugar, bread, potatoes, cured meat delicatessen, sweets, and preferential use of vegetable oil over olive oil in cooking) dietary pattern. Each participant was assigned two scores, representing the degree to which she followed each dietary pattern. A woman was considered to follow an unhealthy diet when her score for following an unhealthy dietary pattern exceeded that of her score for following a healthy dietary pattern.

According to women's self report, we considered never-smokers, former smokers (but not in the past year), and smokers (daily use of tobacco products). Finally, women were divided in three groups according to self reported consumption of alcohol: abstinents, moderate consumers (on average one drink each day), and excessive consumers (more than one drink each day, on average, or a binge at least once each month, defined as 6 drinks or more on one occasion). One drink was defined as one bottle of beer, 1 decilitre of wine, or 0.3 decilitre of spirits.

We used SAS, version 9.1, SAS institute Inc., Cary, NC, USA. The study was approved by the Zagreb University School of Medicine Ethics Committee.

\section{Results}

A total of 1,999 women of childbearing age participated in the survey in 2003 (median age 34 years, inter-

TABLE 1

POPULATION PREVALENCE OF ABDOMINAL OBESITY, GENERALISED OVERWEIGHT AND OBESITY, AND HIGH RISK HEALTH BEHAVIOURS AMONG CROATIAN WOMEN OF CHILDBEARING AGE

\begin{tabular}{lcr}
\hline & 2003 & 2008 \\
$\%(95 \% \mathrm{CI})$ & $70.28(61.81-75.74)$ \\
\hline Abdominal obesity* & $50.28(45.28-55.28)$ & $48.64(42.56-54.72)$ \\
Abdominal obesity $\dagger$ & $29.23(25.34-33.12)$ & $52.47(46.61-58.33)$ \\
Generalised overweight $(25 \leq \mathrm{BMI}<30)$ & $35.62(30.37-40.86)$ & $27.21(22.28-32.14)$ \\
Generalised obesity $(\mathrm{BMI} \geq 30)$ & $10.83(7.93-13.73)$ & $48.28(43.93-52.62)$ \\
Unhealthy diet & $52.00(46.66-57.35)$ & $63.18(55.43-70.93)$ \\
Physical inactivity & $61.08(54.23-67.92)$ & $62.27(56.81-67.74)$ \\
Sedentary lifestyle & $54.83(49.14-60.53)$ & $3.10(1.42-4.78) \S$ \\
Excessive consumption of alcohol§ & $0.97(0.22-1.73) \S$ & $32.43(26.61-38.24)$ \\
Smoking & $35.15(29.84-40.47)$ & \\
\hline
\end{tabular}

* IDF (International Diabetes Federation) criterion; waist circumference $\geq 80 \mathrm{~cm}$ indicates abdominal obesity

$\uparrow$ NCEP ATP III (National Cholesterol Education Program, Adult Treatment Panel III) criterion; waist circumference $\geq 88$ cm indicates abdominal obesity

$\S$ unreliable estimate 
quartile range 28 to 40 years). In the second cycle, in 2008 , we managed to directly or indirectly (through other household members or neighbours) contact 1,161 of these women (58.08\%). Of these, 598 women $(51.51 \%)$ agreed to participate in the second cycle of the survey. Reasons for rejection were time constraints (149 women, or $15.13 \%)$, poor previous experiences with interviewers (6 women, or $0.61 \%$ ), lack of interest (128 women, or $12.99 \%$ ), unable to participate due to illness (20 women, or $2.03 \%$ ), death (44 women, or $4.47 \%$ ), and other reasons (638 women, or $64.77 \%$ ), which most commonly included various combinations of the reasons above.

The prevalence of abdominal obesity according to the IDF criterion (waist circumference $\geq 80 \mathrm{~cm}$ ) increased between 2003 and 2008 from $50.28 \%$ to $70.28 \%$ (Table 1). Using the NCEP ATP III criterion (waist circumference $\geq 88 \mathrm{~cm}$ ), the prevalence increased from $29.23 \%$ to $48.64 \%$. We also detected an increase between the two survey cycles for generalised overweight and obesity, as well as for high risk behaviours physical inactivity, sedentary lifestyle, and excessive consumption of alcohol; the latter estimate however was considered unreliable due to a high coefficient of variability. Decreases were seen between the two survey cycles in the prevalence of unhealthy diet and smoking.

In the subgroup of women with waist circumference below $80 \mathrm{~cm}$ in 2003 , the five-year cumulative incidence of abdominal obesity as per the IDF criterion was estimated at $54.34 \%$ (Table 2). Among these women, the prevalence of most high risk behaviours declined between the two survey cycles, except for sedentary lifestyle, the prevalence of which increased from $55.25 \%$ to $61.46 \%$.

Among women without abdominal obesity according to the NCEP ATP III criterion in 2003, 35.20\% were abdomi-

TABLE 2

FIVE-YEAR CUMULATIVE INCIDENCE OF ABDOMINAL OBESITY AND PREVALENCE OF HIGH RISK HEALTH BEHAVIOURS AMONG WOMEN FREE OF ABDOMINAL OBESITY AT BASELINE*

\begin{tabular}{|c|c|c|}
\hline \multicolumn{3}{|c|}{ Women free of abdominal obesity at baseline* } \\
\hline & & $\%(95 \% \mathrm{CI})$ \\
\hline \multicolumn{2}{|c|}{ Five-year cumulative incidence } & $54.34(44.54-64.15)$ \\
\hline \multirow{2}{*}{ Physical inactivity } & 2003 & $64.07(56.34-71.79)$ \\
\hline & 2008 & $61.63(52.22-71.05)$ \\
\hline \multirow[t]{2}{*}{ Sedentary lifestyle } & 2003 & $55.25(48.27-62.23)$ \\
\hline & 2008 & $61.46(55.77-67.15)$ \\
\hline \multirow[t]{2}{*}{ Unhealthy diet } & 2003 & $48.99(41.29-56.69)$ \\
\hline & 2008 & $45.38(38.63-52.12)$ \\
\hline \multirow{2}{*}{$\begin{array}{l}\text { Excessive consumption } \\
\text { of alcohol } \dagger\end{array}$} & 2003 & $1.28(-0.00-2.56) \dagger$ \\
\hline & 2008 & $4.19(1.53-6.86) \dagger$ \\
\hline \multirow[t]{2}{*}{ Smoking } & 2003 & $41.64(34.17-49.11)$ \\
\hline & 2008 & $38.11(29.64-46.58)$ \\
\hline
\end{tabular}

\footnotetext{
* IDF (International Diabetes Federation) criterion; waist circumference $\geq 80 \mathrm{~cm}$ indicates abdominal obesity

† unreliable estimate
}

TABLE 3

FIVE-YEAR CUMULATIVE INCIDENCE OF ABDOMINAL OBESITY AND PREVALENCE OF HIGH RISK HEALTH BEHAVIOURS AMONG WOMEN FREE OF ABDOMINAL OBESITY AT BASELINE*

\begin{tabular}{lcc}
\hline \multicolumn{2}{c}{ Women free of abdominal obesity at baseline ${ }^{*}$} \\
\hline \multicolumn{2}{l}{$\%(95 \%$ CI $)$} \\
\hline Five-year cumulative incidence & $35.20(27.98-42.42)$ \\
Physical inactivity & 2003 & $61.71(53.91-69.51)$ \\
& 2008 & $63.21(54.48-71.93)$ \\
Sedentary lifestyle & 2003 & $56.16(47.83-64.49)$ \\
& 2008 & $65.70(59.20-72.21)$ \\
Unhealthy diet & 2003 & $49.39(43.96-54.82)$ \\
& 2008 & $47.42(42.49-52.35)$ \\
Excessive consumption & 2003 & $1.03(0.08-1.98) \dagger$ \\
of alcohol $\dagger$ & 2008 & $3.49(1.36-5.62) \dagger$ \\
Smoking & 2003 & $38.34(31.89-44.79)$ \\
& 2008 & $36.46(28.46-44.45)$ \\
\hline
\end{tabular}

* NCEP ATP III (National Cholesterol Education Program, Adult Treatment Panel III) criterion; waist circumference $\geq 88 \mathrm{~cm}$ indicates abdominal obesity

† unreliable estimate

nally obese five years later (Table 3). Between the two survey cycles, the prevalence of unhealthy diet and smoking decreased in this subgroup, whereas the prevalence of physical inactivity and sedentary lifestyle increased.

\section{Discussion}

Our results show a high and quickly increasing burden of abdominal obesity among Croatian women of childbearing age. Prevalence was already high at baseline, in 2003, with about half of women abdominally obese, as defined by the $80 \mathrm{~cm}$ waist circumference cut-off, and nearly a third as defined by the $88 \mathrm{~cm}$ cut-off. Moreover, by 2008 , about $70 \%$ of women were abdominally obese using the $80 \mathrm{~cm}$ cut-off, and nearly half using the $88 \mathrm{~cm}$ cut-off. Over the five studied years, more than half of Croatian women of childbearing age became abdominally obese using the $80 \mathrm{~cm}$ waist circumference cut-off, and more than a third became abdominally obese using the $88 \mathrm{~cm}$ cut-off. The rise in the burden of abdominal obesity exceeded that of a rise in generalised overweight and obesity, which is consistent with some previous reports ${ }^{18-20}$ but not with others ${ }^{21,22}$.

Also of concern are high prevalence rates of high risk health behaviours. Our estimates indicate that nearly half of Croatian women of childbearing age ate unhealthy diets and nearly two thirds were physically inactive or even sedentary in 2008. From a general public health perspective, it is encouraging to see that the prevalence of smoking dropped below a third between the two survey cycles, from $35.15 \%$ in 2003 to $32.43 \%$ in 2008 , although this may have contributed to an increase in the prevalence of obesity. It is also good to see that more than 
half of Croatian women of childbearing age consume on average one alcoholic drink each day, as such consumption levels may protect against cardiovascular disease, compared with abstinence or higher consumption ${ }^{23}$. Still, it is unclear how reliable these estimates are, given the self reported nature of the data and a very low proportion of women who reported consuming on average more than one drink per day. Socially desirable answers may have taken place of truthful answers in some instances, but our survey did not contain a »lie» item that would allow for estimating this with any certainty.

Baseline characteristics differed somewhat between respondents to both cycles and those who only participated in 2003 (data not shown). Those who chose to participate in the second cycle more often ate unhealthy diets and were more often sedentary at baseline, compared with women who only participated in the first cycle. However, we did not detect any differences between these two groups in baseline abdominal obesity, physical inactivity, smoking, or alcohol consumption. Socioeconomically disadvantaged women more often chose to participate in the second cycle, and abdominal obesity was more common among women with lower socioeconomic position. For these reasons, it seems that our results may be somewhat overestimated. Still, we believe we have demonstrated worryingly high prevalence and incidence rates of abdominal obesity among Croatian women of childbearing age, which require immediate policy attention and public health action.

\section{Acknowledgement}

This research was supported by the Croatian Ministry of Science, Education and Sport (Project Number: 1081080135-0264).

\section{R E F E R E N C E S}

1. ECKEL RH, Int J Obes, 32 (2008) S143. — 2. FIŠTER K. BMJ, 330 (2005) 618. - 3. SAARNI SE, PIETILAINEN K, KANTONEN S, RISSANEN A, KAPRIO J, Am J Public Health, 99 (2009) 348. — 4. KUCZMARSKI RJ, FLEGAL KM, CAMPBELL SM, JOHNSON CL, JAMA, 272 (1994) 205. - 5. KAHN HS, CHENG YJ, Int J Obes (London), 32 (2008) 136. - 6. JOHNSON K, POSNER SF, BIERMANN J, CORDERO JF, ATRASH HK, PARKER CS, BOULET S, CURTIS MG; CDC/ATSDR PRECONCEPTION CARE WORK GROUP; SELECT PANEL ON PRECONCEPTION CARE, MMWR Recomm Rep, 55 (2006) 1. - 7. ASHTON DM, LAWRENCE HC 3RD, ADAMS NL 3RD, FLEISCHMAN AR, Obstet Gynecol, 113 (2009) 925. - 8. THE ROYAL SOCIETY OF MEDICINE, Obesity problems begin before conception, accessed 07.06.2009. Available from: URL: http://www.roysocmed.ac.uk/media/pr278.php. - 9. MATSUZAWA Y, Int J Obes, 32 (2008) S83. - 10 WORLD HEALTH ORGANIZATION, Fact sheet No 317 - Cardiovascular diseases (CVDs), accessed 23.05.2011. Available from: URL: http://www.who. int/mediacentre/factsheets/fs317/en/index.html. - 11. Croatian Health Service Yearbook (Croatian National Institute of Public Health, 2009). - 12. FIŠTER K, Modifiable risk factors for abdominal obesity in women of childbearing age. PhD Thesis. In Croat (University of Zagreb, Zagreb,
2011). — 13. BÉLAND Y, BAILIE L, PAGE J, Statistics Canada, Croatian Ministry of Health and Central Bureau of Statistics: a joint effort in implementing the 2003 Croatian Adult Health Survey, American Statistical Association, accessed 11.08.2011. Available from: URL: http://www.amstat.org/ sections/srms/proceedings/y2004/files/Jsm2004-000700.pdf. - 14. IVIČEVIĆ UHERNIK A, VULETIĆ S, KERN J, DEČKOVIĆ-VUKRES V, MIHEL S; ERCEG M, PRISTAŠ I, Coll Antropol, 36 Suppl 1 (2012) 3. - 15. RANKINEN T, KIM SY, PÉRUSSE L, DESPRÉS JP, BOUCHARD C, Int J Obes Relat Metab Disord, 23 (1999) 801. — 16. ALBERTI KG, ZIMMET P, SHAW J, Diabet Med, 23 (2006) 469. - 17. NATIONAL INSTITUTES OF HEALTH, Obesity Res, 6 (Suppl 2) (1998) 51S. — 18. LIESE AD, DORING A, HENSE HW, KEIL U, Eur J Nutr, 40 (2001) 282. — 19. MCCARTHY HD, ELLIS SM, COLE TJ, BMJ, 326 (2003) 624. - 20. LISSNER L, BJORKELUND C, HEITMANN BL, LAPIDUS L, BJORNTORP P, BENGTSSON C, Int J Obes Relat Metab Disord, 22 (1998) 1116. - 21. BERG C, ROSENGREN A, AIRES N, LAPPAS G, TORÉN K, THELLE D, LISSNER L, Int J Obes Relat Metab Disord, 29 (2005) 916. - 22. VISSCHER TL, SEIDELL JC, Int J Obes Relat Metab Disord, 28 (2004) 1309. - 23. RONKSLEY PE, BRIEN SE, TURNER BJ, MUKAMAL KJ, GHALI WA, BMJ, 342 (2011) d671.

\section{K. Fišter}

University of Zagreb, School of Medicine, "Andrija Štampar « School of Public Health, Rockefellerova 4, 10000 Zagreb, Croatia

e-mail:kfister@snz.hr

\section{PREVALENCIJA I PETOGODIŠNJA KUMULATIVNA INCIDENCIJA ABDOMINALNE PRETILOSTI U ŽENA FERTILNE DOBI U HRVATSKOJ}

\section{S A Ž E T A K}

Predloženo je da se javnozdravstveni napori koji za cilj imaju kontrolu pretilosti usredotoče na žene fertilne dobi. Prevalencije su prekomjerne generalizirane debljine i generalizirane pretilosti u porastu, kako globalno tako i u Hrvatskoj, međutim slabije su istraženi trendovi u prevalenciji abdominalne pretilosti. U prvom krugu Hrvatske zdravstvene ankete 2003. godine sudjelovalo je 1.999 žena fertilne dobi, od kojih je 598 (29,9\%) sudjelovalo i u drugom krugu 2008. godine. Patronažne sestre mjerile su struk sudionica u oba kruga ankete. Za 2008. godinu, procijenili smo da je prevalencija abdominalne pretilosti po IDF kriteriju (od International Diabetes Federation) (opseg struka $\geq 80 \mathrm{~cm}$ ) među 
ženama fertilne dobi u Hrvatskoj bila 70,3\% (95\% CI 61,8\% do 75,7\%). Iste godine, prevalencija abdominalne pretilosti po NCEP ATP III kriteriju (od National Cholesterol Education Program, Adult Treatment Panel III) (opseg struka $\geq 88$ $\mathrm{cm}$ ) bila je u ovoj populacijskoj podskupini 48,6\% (42,6\% do 54,7\%). Kumulativna incidencija za prethodno petogodišnje razdoblje iznosila je 54,3\% (44,5\% do 64,2\%) po IDF kriteriju odnosno $35,2 \%$ (28,0\% do 42,4\%) po NCEP ATP III kriteriju. Zaključujemo da je breme abdominalne pretilosti veliko i pokazuje brzi trend rasta među ženama fertilne dobi u Hrvatskoj, ključnoj populacijskoj podskupini za kontrolu pretilosti. 